\title{
Dr. James's Fever Powder and other Georgian remedies
}

\author{
Alan Mackintosh: The patent medicines industry in Georgian \\ England: constructing the market by the potency of print. London: \\ Palgrave-Macmillan, 2018, xvi+320pp, $94.94 € \mathrm{HB}, 74.89 € \mathrm{~EB}$
}

\author{
Jonathan Simon ${ }^{1}$
}

Published online: 29 July 2020

(c) Springer Nature B.V. 2020

Patent medicines were only outlawed in Britain in 1941, less than 100 years ago. Before this, they supported a flourishing business sector that Alan Mackintosh analyses for the period running across the eighteenth century and into the first decades of the nineteenth. What is new and non-obvious about Mackintosh's book on patent medicines is the author's painstaking archival research. He has brought together diverse sources to generate empirical data from which he draws conclusions about the nature and functioning of this market. If you were labouring under certain caricatural preconceptions, such as the image of the mountebank selling his doubtful panacea from the back of a covered wagon (a more American than British caricature, it must be said), then this book will serve as a healthy antidote.

Mackintosh highlights not only the profitability of patent medicines, which comes as no surprise, but also the respectability of the business, at least in the eighteenth century. He cites several businessmen, whom he terms 'market leaders' to distinguish them from the more numerous and modest tradesmen and women in the field, who rose to the status of landed gentry thanks to the profits generated by the sale of these drugs. He even includes a portrait of an established gentlewoman, Elizabeth Shackleton, who produced a treatment for rabies as a philanthropic venture. Nevertheless, Mackintosh's favourite subject is Francis Newbery, one of these market leaders, who multiplied a family fortune thanks to the enduring and regular sales of Dr. James's Fever Powder. Mackintosh opens and closes his book with reflections based on the biography of this successful businessman (and his father John) who specialised in the trades of drugs and the printed word. The connection between the trade in books and the trade in patent medicines leads Mackintosh to the most original, and, for me, least convincing part of the book: his hypothesis about the reason for the success of the patent medicine trade. The question he poses is the following. Why was this market in patent medicines so successful, when there is little reason to

Jonathan Simon

Jonathan.simon@univ-lorraine.fr

1 Archives Poincaré, UMR 7117, Université de Lorraine, Nancy, France 
believe that these products were effective in treating the diseases mentioned in the advertisements or handbills? He floats the hypothesis that these medicines gained their efficacy through the manipulation of the imagination, an effect brought about by the printed word. In a variation of the 'placebo effect', the newspaper advertising worked on the reader's imagination to render these medicines effective. Paradoxically, when one considers the solidity of the other empirical arguments in the book, this hypothesis is not backed up by any pertinent data. It seems to me that the 'Donald Trump hypothesis' would work just as well in this context; when asked why he took the anti-malaria drug hydroxychloroquine to prevent Covid-19, Donald Trump replied, 'Because I think it's good. I've heard a lot of good stories. And if it's not good, I'll tell you right. I'm not going to get hurt by it.' No need to explain the choice of the American President by his imagination being over-excited by the news media! Still, you do not have to swallow Mackintosh's imagination theory in order to appreciate this book, just because of the sheer weight of the research data that he has put together to further our understanding of the business of medical drugs in the eighteenth century. Just as an example, the author exercised considerable historical flair when he looked at the number of times the printing blocks for the excise stamps were renewed in order to estimate the sales of the medicines that required paying this tax. And the issues of taxation and regulation are significant ones that Mackintosh brings to the fore. In a largely unregulated pharmaceutical market, it is striking how important national laws, provisions and ultimately taxes were in the construction of the patent medicine business.

The original meaning of a patent medicine in the UK is a medicine that has been granted a royal patent. The term soon became generic, and, as it turns out, very few of these mass-produced pre-packaged medicines had ever received one of these royal patents. What made these drugs particularly difficult to monitor and police, however, was the characteristic feature of a generic patent medicine: that the producers did not list the ingredients (in order to avoid competitors producing counterfeit versions), and so it was hard to know what was in them. Nevertheless, legislation was important to the patent medicines market, albeit fiscal rather than public-health legislation, particularly the introduction of the Medicine Excise Stamp associated with a new stamp duty in 1783. This tax measure was aimed at raising funds from a thriving market, and, despite a slow start, it seems to have been quite successful. Although it was just an acknowledgement that the product's owner had paid the appropriate tax, in the eyes of the public the excise stamp seems to have become an ersatz for the official approval of a medicine (although no approval system was in place), and the stamp itself regularly featured in newspaper advertisements for the product.

Mackintosh has also undertaken a systematic sampling of a number of local newspapers, the Leeds Intelligencer, Leeds Mercury, Aris's Birmingham Gazette and the Salisbury and Winchester Journal, to assess the reality of what is found in the advertisements for these patent medicines. Once again, his empirical approach allows him to demolish several myths that have been propagated by well-known historians of medicine: that patent medicines were usually presented as panaceas and that they were principally marketed by using testimonials from authority figures, to name but two. Of course, the advertisements that make wildly unrealistic claims and 
cite colourful personalities in support of their effectiveness are the ones that strike any casual reader who looks through these newspapers, and they are also the ones that make it into general medical history texts. Mackintosh mentions Roy Porter in this context, but underlines that although he might have fallen into this trap, he was one of the few historians to have taken a serious interest in the patent medicine business (Porter 1989).

Given his systematic empirical approach to inventorying the content of these advertisements, Mackintosh is quite right to underline that it is a fallacy to take these attention-grabbing ads as the norm, and to conclude, quite wrongly, that the patent medicine business was all about quackery and fantastic overblown claims. The advertisements mostly relied on plain informative accounts of who produced the medicines and where they could be purchased. Of course, the colourful figures and the exaggerated claims are the ones that are usually cited by historians, but they are unrepresentative of a serious and essentially respectable business.

Another novel observation supported by his study of the market is that the patent medicine trade was closely linked to the print trade. Despite Mackintosh's imagination thesis that claims a necessary functional connection between the two, the link seems to be one based on the similarity of the products (centrally produced, before being distributed for repeated individual domestic consumption). Thus, the patent medicine trade could capitalise on the distribution and sales networks already in place for books and newspapers, and we might not have to postulate any deeper mutual dependence between the products.

Overall, Mackintosh offers us a very interesting bottom-up approach to the history of medicines that provides a model for those with the patience and commitment to pull together the diverse sources of empirical data that are available in archives around the world. Through this painstaking empirical research, Mackintosh has provided invaluable information about the reality of the medicines business in eighteenth-century Britain.

\section{Reference}

Porter, Roy. 1989. Health for Sale: Quackery in England 1660-1850. Manchester: Manchester University Press.

Publisher's Note Springer Nature remains neutral with regard to jurisdictional claims in published maps and institutional affiliations. 